\title{
THE SOVIET TRANSITION FROM SOCIALISM TO CAPITALISM: WORKER CONTROL AND ECONOMIC BARGAINING IN THE WOOD INDUSTRY*
}

\author{
MichaEl BURAWOY \\ University of California, Berkeley
}

\author{
PAVEL Krotov \\ Russian Academy of Sciences
}

\begin{abstract}
Analyses of the transition from state socialism to capitalism typically focus on political impediments and underestimate the economic obstacles to economic transformation. Based on a case study of the Soviet wood industry, we argue that there will be no economic transition so long as enterprises retain two historic features, namely anarchy in production and bargaining in external relations. Far from constituting a revolution, the withering away of the party state has exaggerated the pathologies of the old economic order. Barter has become more important, conglomerates have strengthened their monopoly and workers have greater control of the shop floor. If there is a movement toward a market economy at all, it is toward a form of merchant capitalism that deepens economic underdevelopment and thwarts the rise of modern bourgeois capitalism.
\end{abstract}

W hereas for the first half of the twentieth century socialism was regarded as a real alternative to capitalism, now it appears to be no more than a will-o'-the-wisp. In advanced capitalism, the obstacles to the transition to socialism have been multiple and diverse: capitalism has been able to overcome the crises it generates by continually revolutionizing itself as its epicenter shifts from nation to nation; the state has effectively orchestrated economic relations and incorporated different groups into the capitalist order. In particular, the working class, the supposed agent of the transition to socialism, has failed to become a revolutionary class - it has been ei-

- Direct all correspondence to Michael Burawoy, Department of Sociology, University of California, Berkeley, CA 94720. We would like to thank the managers and workers at Polar Furniture as well as all the other people we interviewed in connection with this study. We are particularly grateful to the Trade Union Federation of the Republic of the North and to Dr. Tamara Kalyanova for support throughout the research. In addition to the ASR editor and two anonymous referees we thank Kathryn Hendley, Neil Fligstein, Erik Wright and members of the Smith Dissertation Group - Bob Freeland, Mary Kelsey, Hyun Ok Park, Chris Rhomberg, Brian Rich, Suava Salameh, Anders Schneiderman, Rob Wrenn, and Mona Younis. Their comments became the basis for rewriting the paper. Burawoy's research was partially supported by grants from the MacArthur Foundation and the Social Science Research Council, administered through IREX. All names which appear in the text are pseudonyms. ther too weak or where it has been strong it has advanced its interests within capitalism rather than against it. The forces of international capitalism have conspired to defeat attempts to install socialism through economic strangulation or direct political intervention. Finally, the unattractiveness of existing forms of socialism and the lack of plausible socialist alternatives have made the projected transition utopian.

In contrast, the conditions for the transition from state socialism to capitalism are propitious. First, far from overcoming the crises it generated, Soviet state socialism succumbed to economic stagnation. There is general agreement that the Soviet economy began to decline in the early 1970s, a decline from which it never recovered. Second, the party state not only failed to effectively coordinate the economy, but in the Soviet Union, at least, it also failed to develop adequate auxiliary markets that would fill the "functional gaps" left by planning. Third, the Soviet regime had limited success in eliciting the active consent of subordinate groups, including the workers but more importantly intellectuals, who often headed opposition to the party state. As perestroika unfolded, large fractions of the Soviet leadership abandoned their allegiance to a socialist future, turning their backs on the past as an embarrassing failure. Fourth, international political and economic forces are conspiring to promote the most rapid transition to capitalism possible. Economic aid is made contingent on introducing a stable monetary system, liberalizing pric- 
es, privatizing state enterprises and bringing down tariff barriers. Fifth, even if there is no strong internal bourgeoisie, still capitalism has a magical appeal to all strata in Soviet society - the possible delivery from an economy of shortages and all the deprivation and degradation that this entails. Finally, the transition is not utopian there are concrete examples of "successful" capitalist societies, from Sweden to Germany, from the United States to Japan, from South Korea to Taiwan. In short, if ever there were favorable circumstances for a transition from one economic system to another, they surely exist in the new Commonwealth of Independent States.

At least in their rhetoric and their programs, this optimism is echoed by the teams of Soviet "economic experts" who have been planning the transition to capitalism. For example, the fivehundred-day Shatalin plan, largely designed by Yavlinsky and his collaborators, left little to chance - it laid out a detailed week-by-week program to be implemented during each of four phases. Such programs bear the marks of the old Soviet order, not only in their devotion to planning but also in their reliance on transforming the existing order through ideological mobilization and political decree. For seventy years ideology and politics were directed to the most rapid construction of socialism, now they have become instruments for the most rapid transition from socialism to capitalism. New legislation has followed new legislation: the law on individual labor activity (1986), the law on the state enterprise (1987), and the law on cooperatives (1988), culminating in the law on ownership (1989) that in principle legalized the capitalist enterprise (Pomorski 1991). These laws permitted new forms of organization and ownership - from cooperatives to small enterprises, from leasing agreements to companies of limited liability, from joint ventures to joint stock companies.

While Soviet scholars and journalists as well as politicians riveted their attention first on the legislative enactment of economic reform and then on the formal dissolution of the party state, there has been little regard for the effects of these changes on existing social relations either within or between enterprises. Actual economic relations continue to be confused with their juridical expression (Lewin 1974, chap. 8; Bettleheim 1976) as if banning the party marked the removal of the last obstacle to full blown economic reform.

Western scholars subscribe to the same politicized view of the transition from socialism to capitalism. For example, economists Sachs and Lipton (1990, p. 63) claim that the biggest obstacles to the effectiveness of "shock therapy" lie in government responsiveness to popular demands for protectionism or reflating the economy, and in paralyzing debate over privatization. Similarly, political scientist Przeworski (1991, chap. 4) has suggested that the more radical the strategy of transition the more likely it is to succeed but that implementation may be incompatible with liberal democracy. Again, the focus is on the political conditions of transition. In a less sophisticated and more triumphal analysis, historian Malia (1991) celebrated the collapse of theMoscow putsch (August 1991) as sweeping away the past: "For the starkest fact of the Russian Revolution of 1991 is that virtually nothing remains of the old Leninist system. No basic Communist institutions have proved salvageable for a "normal' society" (p. 28). The Revolution installed liberal democracy with the mission "to put an end to the previous regime's equivocations about moving toward a market system and privatizing the economy, and to plunge ahead, while the new government has the country's confidence, with 'shock therapy' on the Polish model, which is in fact their inspiration" (p. 27).

In our view, these commentaries which focus on the political conditions of the transition to a market economy underestimate the capacity of the Soviet economy to reproduce itself and resist transformation. Nor do social surveys designed to assess social support for and resistance to economic reform give an accurate account of economic reality. These surveys may be relevant in the fluid political sphere, but they overlook the way interests are embedded in the day to day operation of the existing economy. Even if all actors proclaimed themselves enthusiastic devotees of capitalism, still, they are locked into a preexisting system of economic relations that is "indispensable and independent of their will" (Marx [1859] 1978, p. 4).

In this paper, we argue (1) that the Soviet political regime was not overthrown but that it disintegrated; (2) that the decomposition of the party neither eliminated all obstacles to reform nor reduced the economy to complete chaos; and (3) that even in the unlikely event that liberal democracy should establish itself, it would not have the capacity to transform a tenacious Soviet economy. Our argument is simple. We have not been witnessing a "revolution," but the (long anticipated!) withering away of the state. Left behind is an economy that exhibits many of the tenden- 
cies and pathologies of the Soviet order but in exaggerated form. Specifically, the withering away of the state has given workers greater control of production, has intensified the monopoly of economic conglomerates and has increased primitive bartering among enterprises. The gap between ideology and reality is as wide as ever - the posturing of marketeers hides the resilience of the old economic order. If a transition toward a market economy is taking place at all, it is in the direction of merchant capitalism which, as both Weber and Marx were at pains to demonstrate, is a (real) revolution away from bourgeois industrial capitalism.

\section{IDEAL TYPES OF CAPITALISM AND SOCIALISM}

We need benchmarks to evaluate real changes in the Soviet economy: ideal typical models of where the economy has come from (state socialism) and where it might be going (capitalism). The models draw on a metaframework that defines systems of production by two sets of relations: relations of production through which goods and services are appropriated and distributed, and relations in production that describe the production of those goods and services (Burawoy 1985).

\section{Capitalism}

Marx and Engels defined capitalism as the private appropriation of production and its products, undertaken with a view to accumulating profit in a context of market competition. Capitalists respond to market competition by lowering the costs of labor power (wages), by intensifying labor, by introducing new forms of work organization, and above all, by technological innovations. Once one capitalist innovates, all competitors must innovate on pain of extinction. The gales of creative destruction are inexorable. Capitalists do not know from where the next innovation will come; they only experience it when fellow capitalists undercut them, forcing them to follow suit in an attempt to survive. Thus, individual capitalists find the market to be a sea of uncontrollable forces compelling them to focus their entrepreneurial skills on controlling the process of production.

It became apparent that the production of society at large was ruled by absence of plan, by accident, by anarchy; and this anarchy grew to greater and greater height. But the chief means by aid of which the capitalist mode of production intensified this anarchy of socialized production was the exact opposite of anarchy. It was the increasing organization of production, upon a social basis, in every individual productive establishment. (Engels [1880] 1978, p. 706)

Thus, anarchy at the level of the relations of production leads to planning at the level of relations in production.

From this model of competitive capitalism Marx and Engels demonstrated capitalism's inevitable demise. On the one hand, the pursuit of profit would lead capitalists to transform production, homogenizing the working class, creating a reservoir of unemployment, lowering wages, and intensifying work. Small capitalists would disappear and society would be polarized into two antagonistic classes. Class struggle would intensify. On the other hand, capitalists would accumulate and accumulate, producing more and more goods and services which fewer and fewer people would be able to afford. This would result in crises of overproduction leading to the destruction of capital and its further concentration and centralization. Crises would become deeper and deeper as class struggle intensified.

If Marx and Engels were correct in predicting the demise of competitive capitalism, they nevertheless failed to anticipate the stabilization of a new form of organized capitalism in which competition among capitalists is regulated and class struggle is contained. However, organized capitalism is still capitalism. Regardless of changes in the character of competition, increased state supervision of competition, and the attempts by the largest corporations to eliminate competition, there are still markets, and there is still no agent of superordinate control. In short, organized capitalism did not eliminate the anarchy of the market but reconstructed it in different ways (Fligstein 1990). Indeed some argue that organized capitalism is becoming increasingly disorganized as production becomes internationalized and at the same time fragmented (Lash and Urry 1987).

With the transformation of capitalist relations of production, there have been corresponding changes in the sphere of production. Whereas Marx viewed production planning as despotic and unidirectional, the extension of social guarantees and political rights as well as changing technical requirements prompted management to introduce new forms of labor control. Edwards (1979), Friedman (1977), Wood (1989), and Piore and Sabel (1984) have demonstrated that unidirectional or despotic organization is often counterproductive. Effective planning proves to be a 
relation of domination involving bargaining and compromise. Defining work tasks in minute detail and then insisting on their execution is both technically infeasible and politically disruptive. It is better to elicit workers' cooperation through granting them a degree of autonomy, even though that autonomy is strictly delimited by the application of force. Advancing this literature into the realm of management, Smith (1990) has shown how corporate executives have tried to elicit the participation of middle managers in streamlining their own managerial labor process. Whatever their differences, these studies all agree on two issues: namely the importance of hierarchical control within the enterprise and the multiplicity of its forms. In short, even though capitalism has undergone major transformations in the last hundred years it is still capitalism with anarchic relations of production and planned relations in production.

\section{State Socialism}

Classical Marxism identified the collapse of competitive capitalism with the rise of communism - a new order in which planning would be reconstituted within the workplace and from there would be extended to the entire economy. " $S$ Social anarchy of [relations of] production gives place to social regulation of production upon a definite plan, according to the needs of the community and of each individual" (Engels [1880] 1978, p. 712). Social appropriation would replace private appropriation and the plan would replace the market, while work would be organized by "associated producers, rationally regulating their interchange with Nature" (Marx [1894] 1967, p. 820). Communism was to be a society in which people collectively would make their own history based on their control of the means of production. Both relations of production and relations in production would be subject to planning.

Instead of communism the Soviet Union created an economic order that we call, following Konrád and Szelényi (1979), state socialism, a system characterized by the central appropriation and redistribution of goods and services. However determined central planners were to

\footnotetext{
1 Thus, Engels, Kautsky, and Luxemburg saw the proletarian conquest of power as coinciding with the transition to communism, whereas the novelty of Lenin was to work from Marx's Critique of the Gotha Programme and theorize two stages - a revolutionary transition from capitalism to socialism and an evolutionary transition from socialism to communism.
}

dictate output targets to enterprises, the relationship was in reality one of bargaining in which enterprises sought to minimize what the state appropriated while maximizing what it redistributed. Rather than competition for profits in a market place, central ownership of the means of production led enterprises to maximize their bargaining power within a hierarchy. They did this by seeking to expand the resources they had at their command. Enterprises were not constrained so much by the need to make profit, by what Kornai $(1980,1986)$ calls hard budget constraints, as they were by what the state was prepared to allocate. The insatiable appetite for resources under soft budget constraints created a shortage economy in which enterprises were continually scrambling for materials, technology, and labor. The result was a disjuncture between the logic of allocation and the logic of production. Whereas managers under capitalism can never be sure whether they would be able to sell their products, under state socialism they can never be sure whether they will have the supplies necessary for production. Socialist managers faced continual uncertainty both in the quantity and the quality of materials, technology and labor. In short, planning at the level of the relations of production leads to anarchy of relations in production the very opposite of capitalism.

Of course, capitalist managers also confront uncertainties but they are typically from the demand side. Managers, therefore, can respond, at least in the short term, by expanding or contracting production. Moreover, capitalist managers have the advantage of controlling the labor process. In state socialism the situation is very different. First, supply uncertainty creates much bigger short-term problems for work organization, since it necessitates the continual juggling of the factors of production. Second, and even more important, state socialist managers cannot control the labor process in attempts to adapt to supply shortages. This is because they face not only shortages of materials and technology but of labor as well. Thus, the sanctions management can wield over its work force are limited. Low levels of unemployment, extensive employment rights, and shortages of labor make it virtually impossible for management to control production - they must cede that control to workers (Bahro 1978, pp. 207-10; Holubenko 1975; Ticktin n.d.; Connor 1991, chap. 5). ${ }^{2}$

\footnotetext{
${ }^{2}$ We should distinguish between two explanations of worker power on the shop floor. There are those,
} 
Whether or not anarchy in production gives rise to chaos depends on whether workers use their control in a "negative" or a "positive" way. Even more important, however, are the objective conditions of shortage. In the early period of primitive socialist accumulation associated with the first five year plans of the 1930s and the Second World War appropriation and redistribution were more centralized. To establish the Soviet industrial economy it was necessary to create a labor force out of a primarily peasant population, to construct an infrastructure that would integrate an enormous country into a single economy, and to produce basic materials for a modern industry. It was a period of extensive development whose accomplishment could be measured in quantitative terms. Although primitive accumulation could be and indeed was achieved through command, it created extreme disproportionalities and shortages, not to speak of appalling repression. The state reacted to the economic pathologies it had generated by trying to regulate worker activities through draconian legislation or socialist emulation such as Stakhanovism. Although despotic regimes of production were created, central planners were never able to turn control over production to managers (Filtzer 1986; Andrle 1988; Siegelbaum 1988).

Furthermore, the rational pursuit of plan targets by enterprises generated widespread irrationality from the standpoint of the economy as a whole, such as the concealing of productive capacity, the hoarding of resources, the production of waste, the underestimation of investment requirements to hook planners onto projects, and backward integration with a view to the duplica-

such as Kornai (1980), who have viewed central ownership of production as causing a system of shortages regardless of the specific policies pursued by the center. Others, such as Granick (1987), have argued that job rights and overfull employment are the deliberate policies of central planners, either as part of an implicit contractual relationship with labor or as a distinct commitment to socialist principles. In Granick's view changes in central policy could effectively erode the power of workers while Kornai would see no such possibility. In her recent work on transfers, Hendley (forthcoming) could find no evidence that Soviet managers had taken advantage of new and favorable changes in the law which, in theory, gave them greater control over workers. This points to the autonomous logic of the shortage economy. Of course, where there was neither a shortage of labor nor of physical inputs and where job rights were more limited (as was often the case in the military-industrial complex) managers could exercise greater control over work. tion of supply facilities (Berliner 1957, 1976; Nove 1965, 1983; Kornai 1959; Asselain 1981; Granick 1954, 1967; Hewett 1988; Bauer 1978; Linz 1988; Aslund 1989). These irrationalities became even more harmful to the economy in the period after Stalin's death during the transition from extensive to intensive development, which required more complex production processes and more stringent quality control. Accordingly, the despotic order of command planning gave way to a system of hegemonic planning - an elaborate hierarchical game of negotiated targets, prices, and sanctions governing the appropriation and distribution of resources.

Enterprises were given more autonomy so that managers could devote themselves to garnering supplies some of which were used to bribe workers to cooperate in the fulfillment of plan targets. Unlike other countries such as Hungary, ${ }^{3}$ physical planning remained in place and dampened the incentive for enterprises to overfulfil targets either through innovation or expansion. Managers required minimal cooperation from workers to ensure that plan targets were met, while in turn workers expected managers to deliver adequate supplies and protect a minimum standard of living (Lampert 1985, particularly chap. 5; Lampert 1986). These were the terms of what Voskamp and Wittke (1991, pp. 360-64) call the "planfulfillment pact," which however wasteful endowed work organization with the necessary flexibility to deal with supply shortages. Thus, managers could confront anarchy in production by ceding the shop floor to workers and could compensate for their lack of control over production by seeking to regulate external relations through bargaining.

${ }^{3}$ In Hungary, starting with the new economic mechanism of 1968, fiscal planning replaced physical planning and gave enterprises more autonomy to produce what they wanted and buy what they needed. Managers, therefore, had an interest in extracting more from their workers. But they were also in a better position to exert control. On the one hand, shortages were often less severe so managers could more easily rationalize work organization. On the other hand, they could exercise more control over the labor process because workers could be mobilized on the basis of economic incentives. This was all possible because the expansion of the consumer market and the second economy made it possible to buy almost anything with local currency. However, we should be careful not to exaggerate the differences. Hungarian industry still suffered from shortages and similar trends toward the bifurcation of control can be found (Stark 1986, 1989; Burawoy and Lukács 1992, chap. 4). 


\begin{tabular}{|c|c|c|}
\hline \multirow[b]{2}{*}{$\begin{array}{c}\text { Relations } \\
\text { in Production }\end{array}$} & \multicolumn{2}{|c|}{ Relations of Production } \\
\hline & Planning & Anarchy \\
\hline Planning & $\begin{array}{c}\text { Communism } \\
\text { (1) }\end{array}$ & $\begin{array}{c}\text { Capitalism } \\
\text { (2) }\end{array}$ \\
\hline Anarchy & $\begin{array}{c}\text { State } \\
\text { Socialism } \\
(3)\end{array}$ & $\begin{array}{l}\text { Merchant } \\
\text { Capitalism } \\
\text { (4) }\end{array}$ \\
\hline
\end{tabular}

Figure 1. Four Systems of Production

\section{Transition to a Merchant Capitalism?}

Figure 1 summarizes the distinctions we have made between capitalism, state socialism and communism. In Lenin's model state socialism was to evolve into communism. Although the "dictatorship of the proletariat" has withered away as Lenin anticipated, the current transition is not toward communism. In the official plans of the leaders of Russia and the other nations of the Commonwealth, the desired transition is toward a Western style "market economy," and as before the objectives of the planners are at odds with reality. From the viewpoint of citizens their society is moving neither toward communism nor capitalism but toward a universal bardak (chaos). But is a new order taking shape despite chaos, or even through chaos? We suggest that if there is such an emergent order, it is to be found in cell 4 of Figure 1 where anarchy prevails in both relations in and relations of production. This is not necessarily universal chaos, even if that is how it appears to the participants. Anarchy simply means the absence of any agent of superordinate control - it does not necessarily entail the absence of all coordination.

What then is this new order depicted in cell 4 ? What happens when the party state first withdraws from the economy and then disintegrates leaving enterprises with greater autonomy? We believe that this withering away of the state leads neither to communism nor to bourgeois capitalism but to a form of merchant capitalism. We propose four theses:

(1) Self-generated, lateral linkages between enterprises, which had been restricted and controlled by the party, assume greater importance. This does not involve the rise of markets but the expansion of a system of barter.
(2) As political bodies reconstitute themselves as "parastatal" centers of economic power, regional monopolies intensify whose common objective is the maximization of profits rather than the satisfaction of some socially defined need.

(3) The source of profits is based on trade, speculation, or even extortion rather than on the transformation of production, the "rational capitalistic organization of (formally) free labor" (Weber [1920] 1958, p. 21).

(4) Worker control of production deepens as monopolies become stronger and supply shortages intensify. In effect these monopolies controlling resources become large trading companies which "put out" production to worker collectives located within enterprises.

We develop these theses through a case study of a single enterprise - Polar Furniture Factory in Arctic City. We believe that the systemic features of an economy and how it changes can best be grasped by studying enterprises from the standpoint of what defines and determines success. Polar Furniture is such a successful enterprise. Our explanation for its success is, in part, informed by a comparison with an equally unsuccessful enterprise - Rezina, a rubber factory in Moscow (Burawoy and Hendley forthcoming).

Our field work in Arctic City took place from the end of March 1991 to the end of July 1991. During May and June Burawoy worked as a machine operator at Polar Furniture Factory, while Krotov conducted interviews with the factory's managers. ${ }^{4}$ In April and July we conducted inter-

\footnotetext{
${ }^{4}$ To convey the participatory character of Burawoy's research he is referred to in the first person as "I" throughout this paper. Burawoy secured his job at Polar after being rejected by a number of other enterprises in Arctic City. It was difficult to convince General Directors to give a foreigner permission to work
} 
views with managers in many different enterprises and cooperatives connected with the wood industry as well as with trade union officials, government officials, politicians in the Republic of the North, and executives of the Northern Territories Wood Association. Following the theoretical framework set forth above, our analysis of Polar begins with the relations in production and from there "extends out" to the complex bargaining relations that embed the enterprise within the Republic of the North's wood industry.

\section{WORKER CONTROL OF PRODUCTION}

The main division of Polar Furniture lies toward the outskirts of Arctic City, the capital of the Republic of the North, and has about 1300 employees. It specializes in the production of customerassembled wall units - set combinations of shelves and cupboards made out of pressed wood. In addition the enterprise has three smaller subdivisions. ${ }^{5}$ The first subdivision, which is also the oldest, is also in Arctic city. It produces soft furniture for living rooms (550 employees). The other two subdivisions are in different towns - one subdivision produces bed units (170 employees) and the other kitchen furniture (170 employees). Polar is the only enterprise in the Republic of the North to mass produce these items. During 1990 all these categories of furniture became "deficit" items and virtually unobtainable through state stores.

\section{Marks of Success}

By all appearances, the main division of Polar has been very successful. Its workers were among the highest paid in the city. They received generous zakazi (orders) and could buy additional provisions from the factory shop. ${ }^{6}$ The changing

if they were under pressure from within their enterprise, as was often the case (c.f. Burawoy and Hendley forthcoming). What distinguished Polar was the self-confidence and cohesiveness of its top managers. The General Director was one of the grand old men of the Northern Republic's wood industry - he had little to lose from Burawoy's presence.

${ }^{5}$ Although we refer to Polar Furniture as an enterprise, technically it is a "production association" (proizvodstvennoe ob" edinenie) — an organizational form created by the economic reforms of 1973 (Hewett 1988, pp. 245-56).

${ }^{6}$ In May I was paid 776 rubles before tax and in June 698 rubles, which at the official exchange rate was then equivalent to about $\$ 25$ and $\$ 20$ respectively. There used to be a number of different queues for rooms were spacious and clean. The modern buildings were easily accessible from the main road where signposts boasted the previous year's production figures. A quick tour around the factory with the polished trade union chairman gave us the impression of efficiency and rationality. The workers were young and busy. The plan of production from one shop to the next appeared to be well-organized. It was very noisy and working conditions, particularly in the use of lacquer, were hazardous. When we asked about this, there was a shrug of shoulders - managers said that workers were free to leave, or that workers got used to the lacquer fumes and didn't notice them after a few years.

The Polar Furniture showroom suggested a prosperous enterprise that changed its products regularly. The enterprise even sported its own museum that traced its history from the first artel of furniture makers beginning in 1939 to the modern enterprise of today. Gone were the trappings of communism - there were no photographs of Lenin besides the still obligatory one in the General Director's Office. ${ }^{7}$ Gone were the placards celebrating the virtues of communism. There was no party committee. The last posting on the party notice board - who was to succeed whom in the pyramid of power - was dated 1989. The notice boards for socialist competition, the youth organization, and labor discipline and political obligations were either empty or contained out-of-date decrees that no one had

goods in short supply such as clothes, cars, televisions, and furniture, but in the Spring of 1991 the main queue was for apartments. Employees who received housing in July 1991 had been waiting 12 years, a much shorter time than the average wait of 20 years at other enterprises. Food was available in parcels known at Polar as nabor (set). During the two months I worked there I was able to buy two packages, each of which contained 1.5 kilos of sausage and 5 eggs. On other occasions I was able to order honey and tinned meat. Because our work was "dangerous" we received coupons for milk, but it was not always available. On one occasion we were able to buy our monthly ration of sugar ( 1.5 kilos per person) at the enterprise. The city council distributed ration coupons (taloni) but there was no guarantee that we would ever find the rationed food in the stores, so allocation at the enterprise was crucial.

${ }^{7}$ Actually, I did discover another photo - a very dusty one on top of my drilling machine. When I asked my workmate Sergei what Lenin was doing up there he just shrugged his shoulders as if he had never even noticed him. About a month later Lenin suddenly disappeared only to turn up in a pile of rubbish. I seemed to be the only one who noticed his absence. This was in June, before the dramatic events of August 1991. 
bothered to take down. The busiest notice board was titled "Information on Economic Education" - it displayed articles on market research and announced seminars on the "ABC of the market," offered by a local consulting firm. The enterprise sent its deputy director for economic affairs to a two-week business school run by American academics and businessmen.

The enterprise possessed a computer system to record levels of daily production. It had recently obtained modern German production equipment at a cost of 12.5 million marks that was intended to replace older machines and enable the enterprise to develop a new line of furniture made from solid wood. The chief engineer outlined ambitious plans for the reconstruction of the entire enterprise to accommodate the new production process. There was even talk of Polar taking over the neighboring wood processing plant to assure itself of essential supplies for the new furniture. Such moves toward rationalization were not dictated by a state planning agency or by the Ministry but were the initiative of a seemingly dynamic team of Polar's managers. The enterprise had considerable autonomy to set its own prices and its own production profile. It had moved onto arenda (lease) which meant that the enterprise was leased from the state, supposedly a transitional step to full privatization. Far from being stuck in a rigid bureaucratic hierarchy the enterprise appeared to be an independent center of entrepreneurial activity. From this world of appearances let us step into the real world of production.

\section{The Labor Process and Uneven Technology}

I (Burawoy, see note 4) worked for two months in Shop 3, the heart of the factory, drilling holes in panels that would become the "uprights" and "horizontals" of the wall systems. Like everyone else, I was a member of a team and a brigade. There were three teams in my brigade - the drilling team, the team of men who ran the four lines of machines that trimmed the panels to size and taped the edges with veneer and the team of women who cleaned the panels with acetone before sending them on to the next shop. With forty members mine was the biggest brigade in Shop 3 but there were two other small ones. In Shop 2 the major surfaces of the panels were covered with textile paper while in Shop 4 they were lacquered and packaged for customer assembly.

The shop appeared efficient and industriousness and it was laid out in an orderly way. The four parallel line machines, which took the panels from Shop 2, occupied almost half the floor space in our shop. From the line machines operators stacked the panels into banks and pushed them on rollers to the four electronic drills situated opposite the line machines. Each drill was itself set between rollers so that operators had easy access to the banks of panels. We worked in teams of two: one person fed the panels while the other removed them from the conveyor after drilling. We could process a bank of 100 panels in ten minutes. On average we drilled between 1,000 to 1,500 panels in each shift, two to three hours work. The skill lay in setting up the drills so that the holes, up to eleven to a panel, were in exactly the right position, the right size, and the right depth. An experienced operator could set up the machine in twenty minutes. Since we changed the set up only twice or three times a shift, this would add only about another hour to the three hours of drilling.

When we were not setting up or drilling we might engage in chit chat or go to the bathroom for a smoke, but for the most part we disliked being unoccupied. Indeed, to be wandering around the shop floor with nothing to do was a mark of low status. So we would help out with a series of auxiliary operations on smaller shelves or on doors performed on a line of smaller, antiquated, foot driven drills, set up permanently for single operations. Some parts of the wall units, such as the "wing shaped" shelves which often were touched up with a domestic iron, called for delicate attention. The panels that came from the line machines needed to have their edges scraped clean with a knife. Members of the women's team took turns doing this arduous work. ${ }^{8}$

Uneven technology is one of the hallmarks of socialist production. Enterprises used to be given machines by the All-Union ministry or the furniture association to which they belonged. These "gifts" were often inappropriate to the production exigencies of the particular firm and they could be more trouble than they were worth. But enterprises had to accept them if they were ever to receive additional machinery. The main enterprise of Polar Furniture began as an experimental plant in 1978 to test specially designed Soviet

${ }^{8}$ There was a strict gender division of labor - the major exception being our brigade leader, a woman who worked on the drills. Since the women workers shunned me, as they also did most of the Russian men, I did not have the opportunity to probe the intricacies of gender relations at work. 
machinery. But the machinery did not live up to expectations - it produced only half the planned output. In an attempt to make up the loss, the AllUnion ministry gave Polar some German machines in 1980. On that occasion management was lucky - the machines worked extremely well. Among the electronic drills, for example, although the German machine was twice as old as the Soviet and Bulgarian machines, it was still the most efficient and reliable. During the two months I worked on this machine it was down on only two occasions and each time only for a few hours.

While I was working at Polar in 1991, longawaited new machines arrived from Germany. They had been chosen by the enterprise as part of its reconstruction. Even so, problems of uneven development remained. The full potential of the new machinery for Shop 3 could not be realized without a considerable increase in the supply of panels from Shop 2, which looked unlikely. Moreover, the new line of German-made machinery was so advanced that it could effectively do the work of all the existing machines in Shop 3. Yet management did not plan to discard the old machinery because there was no guarantee that they could buy spare parts for the new machinery and because spare parts made domestically often failed to meet foreign machine specifications. Even before the new machines arrived there were two Soviet-made drills in the shop that were permanently out of commission and simply gathering dust.

Regardless, unevenness in technology did not usually interrupt the flow of work. This was because workers, at least within a single brigade, were prepared to move from job to job and machine to machine to pick up the slack. However, worker control over production did not always enhance efficiency.

\section{The Accumulation of Scrap}

The lay out of machines in Shop 3 was indeed efficient; but the resulting distribution of scrap was not. Orderly banks of panels were everywhere stacked on the floor. But many of these banks were defective panels that stayed there as scrap for weeks or even months at a time, and interfered with the work flow. Production was sometimes held up at the beginning of the shift because there was simply no space to move completed work away from the machines and out of the shop - it was a continual juggling act. The problem became particularly acute when we had to make space on the floor for the new German machines.

The accumulation of scrap was a two-fold problem: scrap generation and scrap removal. The official rate of scrap generation in the plan was 2 percent. The nachal' nik (chief) ${ }^{9}$ of the shop said that in reality it was more like 10 percent. It may have been even higher, so lax was the attitude of management toward quality control. For example, there were two inspectors at the drills, both unassertive women with no sanctioning power. In a single shift they might come around once or twice (or sometimes not at all) to see if our holes were in the right place and at the right depth. If they discovered a problem a joking discussion would ensue between them and my workmate Sergei, but the panels would often continue through the plant. In effect, workers themselves were responsible for the quality of the product. Indeed, Sergei regularly checked the holes and if they were out of alignment he would spend considerable time readjusting the drills. I always marvelled at his skill and his determination to get everything just right, even though there was no pressure from above to do so. If we produced scrap, if we ruined an entire bank of panels, if our drilling was imperfect, we were not punished or even warned. The scrap simply piled up on the floor between the machines. Sometimes it was recorded as waste by the quality control department but just as often it was not.

But why was the scrap simply left to accumulate in the shop? Management, claimed there was nowhere to put it. But in reality the scrap problem became particularly acute when management decided to stop selling the scrap for firewood, wanting to sell it instead as finished wood for home use. Management was trying to make a secondary business out of scrap panels but workers were not prepared to collect the scrap unless they received a cut of the profits. Indeed the workers wanted to organize the sale of scrap themselves. At first management was reluctant but as I was leaving at the end of June the nachal' nik was creating a special scrap brigade that would collect usable items and send them on to Shop 4 for lacquering before selling them to stores. Because there were no set prices for scrap and because

\footnotetext{
${ }^{9}$ In charge of each shop was a nachal' nik, the equivalent of a general foreman. Each shift had its own "foreman", known as a master. So as not to confuse these managers with higher levels of management we refer to the nachal'nik and master as shop floor supervisors.
} 
shelving was in such short supply, one nachal' nik suggested they could make more money from scrap than from the completed wall unit kits. Another suggested that management had an interest in declaring a wall unit defective because it could then use it for barter. There were definite fiscal advantages to the accumulation of scrap, but the realization of profits required the cooperation of workers who demanded extra pay for work that was not strictly within their job description.

The generation of scrap in Shop 3 created difficulties for Shop 2 since their plan was based on a 2 percent scrap rate. At the end of every month Shop 2 was under pressure to produce considerably more than planned to make up for the parts wasted in the shops following it in the production process, particularly Shop 3. Tensions intensified because waste in Shops 3 and 4 meant that workers in Shop 2 had to work longer hours to keep up with the demand for panels. On second shift, for example, the workers in Shop 2 often worked until midnight when Shop 3 had already knocked off at 11.00 . The cooperation of workers within shops did not extend to relations between shops.

Top management was aware of the tensions created by its lax control over quality but did nothing. The director for quality control had given 30 years of service to the enterprise, and until recently had been the director for production. She regarded her present position as a sinecure and was pessimistic about any improvement in quality control. She blamed the Soviet system for the lack of interest in quality, the poor pay given to inspectors, and managerial indulgence toward waste makers. She added that high rates of scrap were also a consequence of "declining" discipline of workers and the weakness of the nachal' nik. She herself took no responsibility. Of course, for managers in a shortage economy waste is not as problematic as it is for managers in a surplus economy. Still, the abdication of managerial control over production is part of a broader pattern, epitomized by worker regulation of time.

\section{Flex Time, Soviet Style}

At Polar there was no system of clocking in or out. I began on day shift and quickly learned that work ended before 3:00 p.m. rather than at the official 3:30 p.m. Of course, this meant that there was no contact or exchange of information between shifts. Although we were supposed to meet our master (foreman), Sveta, at 7:00 a.m. on the shop floor, workers might straggle in later without any punishment or even comment. There was a half-hour break at 9:45 a.m. The lunch hour from 12:00 to 1:00 p.m. often began at 11:45 a.m. and if the card game was exciting it might go on until 1:15 p.m. That made the actual work day less than 6.5 hours. Afternoon shift alternated weekly with day shift and began at 3:30 p.m. It ended at 11:00 p.m. rather than the official midnight, which together with the dinner hour and break made the working day a maximum of six hours.

There were also short shifts. Before holidays workers would leave an hour early and Fridays were often cut short by half an hour - even longer if it was second shift and work was slow because it was the beginining of the month. For example, on the first Friday of June workers hosed down their machines three hours early at 7:45 p.m. Sergei turned to me and said we'd better do the same or we'll be the only ones left. Whenever there was no work at our individual machine we felt entitled to leave early. This was one side of the picture. On the other side at the end of the month, we might work intensely, spending a night or two or a Saturday in the factory without overtime pay. Still, the time we "made up" amounted to only a fraction of the time we "cut out" the rest of the month.

The control workers exercised over their own time became clear when the nachal' nik in Shop 4 attempted to fire a worker for absenteeism. According to the law absence without permission for more than three hours was punishable by dismissal. But management must first secure the support of the trade union committee. The worker in question had been absent without permission for two days. At the trade union meeting, which Krotov and I attended, he claimed in his defence that he couldn't find his master to inform her, that his brigade knew he was absent so why did he have to tell anyone else, that he had worked through breaks and dinner periods on previous days to earn the time off, and finally he asked rhetorically what all the fuss was about since his brigade always made the plan. In other words, what he had done was all quite normal. Indeed, when I asked my fellow workers how to request time off they told me to go to the brigade leader rather than Sveta, my master.

In this case the nachal' nik wanted to dismiss the worker because he was a troublemaker. ${ }^{10}$

${ }^{10}$ After examining many instances of dismissal Lampert concluded: "In the great majority of cases 
According to her he had a bad record of discipline and was abusive to master and nachal' nik. In testimony to the influence of the brigade on the shop floor, she defended her action by saying that other brigade members wanted to evict him too. The trade union committee, made up of representatives from the shops, were inclined to support the nachal'nik and approve the dismissal. One representative, however, argued that the nachal' nik should also be disciplined for allowing bad time keeping in her shop. The trade union committee chair agreed and took the view that both worker and supervisors should be disciplined. Thus, the nachal' nik was first criticized for not exercising discipline on the shop floor and then disciplined for trying to enforce a dismissal. This paradoxical state of affairs was an attempt by both management and trade union to undermine the power of shop floor supervisors in favor of worker control.

\section{Ceding Shop Floor Control to Brigades}

Brigade control of the shop floor was strengthened by the payment system. ${ }^{11}$ The wage fund for each brigade was based on the number of parts its members produce. The fund was divided up by leading members of the brigade according to their assessment of each member's "coefficient of labor participation." The premium for plan fulfillment was an additional 75 percent of this basic pay. Shop floor management had no authority to interfere with this distribution, although management might be consulted. This payment system strengthened the autonomy of the brigades

those who are dismissed are seen by management as 'troublemakers' in a broad sense - either because they have flagrantly neglected their work duties and failed to meet their side of the bargain or else because they have fallen out with their superiors and have thus become an embarrassment" (1986, p. 260).

${ }^{11}$ Brigades are not new to the Soviet shop floor. However, in 1979 a resolution was passed to encourage the formation of brigades with greater autonomy to organize, distribute, and remunerate work. In the 1980 s the system spread to most industries so that by the end of the decade over two thirds of workers were enrolled in brigades (Lane 1987, pp. 182-213; Yanowitch 1991, pp. 20-24; Slider 1987; Connor 1991, pp. 179-84). At Polar they introduced the brigade system in 1988. Rather than careful observation of the operation of the brigade system in different settings, Soviet sociologists have used general surveys of the attitudes of workers and managers to evaluate its efficacy. Still, there is every indication that brigades enhance worker control over the shop floor. vis-à-vis the master and nachal' nik who were already cast adrift without support from enterprise administration. But it also fostered the parochial interests of each brigade and thus reinforced unproductive competition and conflict on the shop floor.

For example, poor coordination between Shops 2 and 3 at Polar led to a "war" between shifts in Shop 3. Until the introduction of a new wall unit in 1990 work was coordinated across shops so that the first shift of Shop 3 processed the panels produced by the first shift of Shop 2. When the new wall unit was introduced there were fewer parts but their piece rate prices varied considerably. Rather than pay the two shifts very different rates, the nachal'nik and mastera of Shop 3 decided to amalgamate the work of both shifts, so that each shift processed all the types of panels. However, Shop 2 continued to divide the production of panels between the two shifts. This meant that one of the shifts in Shop 3 had to wait for the delivery of some of the parts at the beginning of each shift making it more difficult for that shift to make the plan each month. This was one source of conflict between the shifts in Shop 3 .

The conflict intensified when the nachal' nik decided to redistribute the work completed by the two shifts so that both made the plan - not just one. My shift appeared to work harder and more efficiently than the other shift. We always made the monthly plan. When the other shift failed to make the plan in May the nachal'nik gave them credit for the excess production from our shift. This led to a walkout by the women workers who formed a tightly organized team in my brigade. Why should they work for the other shift's premium? They were furious.

Hostilities between shops and shifts were publicly displayed when at the beginning of July the deputy director for production posted a public attack on the work patterns of Shop 3. The attack, initiated by the supervisors of Shops 2 and 4 , accused the supervisors of Shop 3 of allowing bad labor discipline, bad time keeping, and the accumulation of scrap. The nachal'nik and the master of my shift were given a disciplinary warning while the master of the other shift was threatened with demotion, which in fact later became reality. Rather than try to coordinate relations between shops and regulate conflict between shifts, the administration abstained from intervention, allowing each shop and shift to carry on struggles in defense of their own interests and at the expense of productive efficiency. Instead of supporting its own shop supervisors, the admin- 
istration publicly humiliated them in front of their own work force. This lack of administrative support for the nachal' nik and mastera was also reflected in the low pay they received - less than some of the workers they supervised. Already in my first month I earned almost as much as Sveta.

Under these circumstances it was naturally very hard to find workers willing to fill these managerial positions. In earlier times the party would call on its members to become shop floor supervisors but with the party defunct recruitment from the shop floor was almost impossible. Either supervisors came from outside the factory, as was the case for the nachal' nik of Shop 3 (who came from the construction industry) and Sveta (who had completed five years in an institute in Moscow), or they were elected from within the brigade (like the master on the other shift). In the case of recruitment from outside, they didn't know the details of the production process. When another of my workmates, Sasha, who had never run the drills, had to take over from Sergei, the usual operator, he never dreamt of asking for help from the master or nachal' nik. Mastera, who were elected from the brigade ranks, pooled their income with the other members of the brigade which then collectively decided how much each received. It was not surprising that the master on the other shift was demoted since he had no sanctions with which to exercise control over the brigade that elected him. Only with difficulty could nachal' niki and mastera elicit respect from workers. At best they could try to coordinate relations within and defend the interests of their respective shift or shop. ${ }^{12}$

Management deliberately undermined the positions of master and nachal' nik. They were sacrificial lambs, punished for not maintaining discipline on the shop floor but at the same time denied the support and resources to maintain that discipline. Rather than agents of higher management in the exercise of control over the shop floor, supervisors were forced to cede power to

\footnotetext{
${ }^{12}$ In their study of Rezina, a Moscow rubber plant, Burawoy and Hendley (forthcoming) describe a different situation in which nachal' niki and mastera tried to take advantage of their autonomy to establish cooperatives in their departments. They were able to offer extra pay to selected workers, three times the usual rate. The nachal' niki could use competition for such lucrative after-hours work to discipline workers during the normal shift. The economic situation of Polar Furniture was much better than Rezina's and management did not encourage such entrepreneurship on the part of the nachal' niki.
}

the brigades in the hope that peace would prevail while management got on with the task of providing the materials of production. As one chief engineer said, "We are frightened of workers. At any time they can stop work and we can do nothing." To give more support to nachal' niki and mastera would be to risk rebellion from the shop floor.

\section{Governing Through the Plan}

To the extent that enterprise management governed at all it was through the plan. Even though management didn't interfere in the process of production on the shop floor, it was nevertheless interested in the fulfillment of its plan. Brigades had no interest in exceeding the plan because any excess might be given to other brigades or might lead to a tighter plan the next month. In this context flexible working hours and autonomous work organization made a lot of sense - they were effective adaptations to a shortage economy. Flexibility and autonomy on the shop floor are necessary when supplies are uncertain, the performance of machinery is erratic, and, most important in this case, when the technology is uneven. In addition, shorter working hours concealed excess labor capacity of the brigade which was easily mobilized when extra effort and longer hours were needed at the end of the month.

Since workers were fired only for either gross violations of the disciplinary code or for making trouble for their bosses (Lampert 1985) and since workers controlled their own pay, mastera were more or less bereft of disciplinary power. If brigades worked an extra shift or two at the end of the month it was usually a decision made by the brigade itself in the light of plan targets. Mastera and even nachal' niki were powerless if the brigade decided otherwise. In Shop 4, for example, toward the end of one month workers threatened to stop work until they were given an extra bonus. Shop floor management opposed the demand and so workers appealed directly to the highest levels of management which granted them their bonus. In exchange for plan fulfillment management ceded control of production to workers, even if this was at the expense of the authority of mastera and nachal' niki.

But in one area shop floor supervisors did exercise influence. Each month production targets were established by the production manager in consultation with the nachal' niki and mastera. At the beginning of every shift we would gather around Sveta to see what we had been assigned 
and how we were doing in relation to the plan. The targets were subject to renegotiation throughout the month, which could cause fluctuating norms for daily output and contradictory requests for parts, particularly at the end of the month. At the end of June 1991, for example, there was some hard bargaining between the nachal' nik of Shop 4 and the production manager. The original plan had called for 3,000 wall units. In the middle of the month it was clear we were not going to make the plan, so it was agreed to adjust the plan downward to 2,700. At the end of the month even this adjusted figure was unrealistic. The production manager relented and gave us the figure of 2,500. In fact the month was particularly bad and we only made 2,036 units. But we still received our premium for making the plan! It was a rare event that workers didn't receive the premium.

How was it possible to not make the plan and still receive the premium? There were actually two plans: a financial plan in rubles set in negotiation with external planners and a production plan set by the enterprise in numbers of wall units and handed down to the shop. Because of fluctuating prices the number of wall units that corresponded to the financial plan varied but it was usually about 1700 . The premium was paid when we made this number although the production plan target for any given month might be much higher - from 2,500 to 3,000. In bargaining with outside bodies management worked with the financial plan while it demanded that the shop floor meet the production plan.

There is an analogue here with the piece rate game of "making out" under capitalism - a game played by dependent individuals under relatively stable conditions (Burawoy 1979). "Making the plan," on the other hand, was played by relatively autonomous worker collectives operating under unstable conditions. The autonomy of the shop floor was secured on the one side by deliberately undermining master $a$ and nachal' niki and on the other side by a payment system regulated by the brigade and based on plan fulfillment. At the same time, the weakness of shop floor supervisors, the abstention of management, and the brigade system of payment led to conflicts between shifts and shops. Management was content with this "plan-fulfillment pact" (Voskamp and Wittke 1991, pp. 360-64) as long as minimal plan targets were met and workers' opposition was deflected into lateral conflict or onto the nachal' niki.

From a capitalist perspective it is difficult to understand how such anarchy in production could lead to an enterprise as successful as Polar Furniture. The secret of the capitalist enterprise lies in managerial control over production, a control entirely absent at Polar. In contrast to the capitalist enterprise, the secret of the successful Soviet enterprise lies in its bargaining relations with external organizations. "The successful 'entrepreneur' in this [Soviet] system is not a person who develops new products and new technologies, but one who successfully develops a workable relationship with the government and party authorities supervising his enterprises" (Hewett 1988, p. 199). Here, Polar was clearly successful.

\section{BARGAINING WITH EXTERNAL ORGANIZATIONS}

In a shortage economy the most important constraints on an enterprise are from the supply side - material resources, human resources, and investment resources. In the Soviet Union the organization of supply operated at three levels. At the first level were All-Union ministerial organs, at the second level were government and party organs of the Republic of the North, and at a third level were direct contractual relations between enterprises, based on barter. Under the old system, that is to say until 1987 when the Law on the State Enterprise introduced "state orders" as a substitute for rigid plan targets (Osborn 1991; Kushnirsky 1991; Pomorski 1991), All-Union ministries were most important in guaranteeing supplies. Territorial organs played a similar role but were subordinate to central ministries and bartering, where it existed, was regulated by the party. Today in the wood industry the All-Union ministry has become a parastatal "concern" that is a business association of its own and has ceded control of most enterprises to territorial organs, particularly to the regional wood industry conglomerate, the Northern Territories' Wood Association (NTWA), but also to the Republic's Council of Ministers. At the same time enterprises barter on their own behalf or through cooperatives to obtain products they cannot get through the territorial organs.

\section{Factors Contributing to Success: Supply, Barter, Prices, and Influence}

The basic material for the production of wall units, wood, was also a major product of The Republic of the North. Wood cutting was based in logging villages from where it was transported to logging enterprises. From there it was shipped by road or 
river to wood processing plants. Polar Furniture used pressed wood obtained from two factories - the better quality wood came from an auxiliary plant of the local paper mill. Textile paper was also relatively easily obtained, either from $\mathrm{St}$. Petersburg or imported. According to the Director for Supplies the most serious problems were posed by shortages of the high quality plywood veneer that came from outside the Republic of the North, of imported lacquer and of mirrors that came from Baku. For Polar, then, the first conditions of success were met - major raw materials were readily accessible and its supply profile was relatively simple. This already put Polar Furniture at an advantage relative to other enterprises such as Rezina. ${ }^{13}$

A second factor that favored Polar Furniture is the "barterability" of its product. During the year previous to our field work, wall units had completely disappeared from the shops and so they were in particularly high demand. As an essential part of every apartment, they could be used as hard currency when things were needed, be it food provisions for workers, places in kindergarten, holiday homes for employees, or mirrors from Baku. Both the finished wall units and stocks of pressed wood were bartered for things urgently required. It appeared that all Polar's major department heads were involved in bartering wall units to get what they needed, although the entire process was regulated by the General Director. Responding to the pressures of a shortage economy the General Director himself took every opportunity to demand that in return for fulfilling state orders the government guarantee not only Polar's supplies but also that 20 percent of its product be available for barter.

The third factor favoring Polar was the pricing of its product. Polar was not dependent on fixed state prices but negotiated "contractual" prices based on a system of cost plus profit. When managers wanted to increase the price of a particular wall unit or introduce a new one they submitted an account of the new costs to the government of the republic. It was generally approved without questions and by the middle of 1991 Polar could increase the wages and premiums of its workers

\footnotetext{
${ }^{1.3}$ Our theory of success, in part, derives from the study of this Moscow rubber enterprise which was in perpetual economic crisis. Rezina's production was dependent on a vast array of chemical supplies, its products were not readily barterable, many of its products had state regulated prices, and it did not have a cozy relationship with any production "association" or "concern" (Burawoy and Hendley forthcoming).
}

by an equivalent amount. Other enterprises, such as the logging enterprises, faced regulated state prices for their product and they had much less room to maneuver. Increasing product prices had implications for plan fulfillment since the plan, and therefore the amount Polar had to give up to the state, was based on rubles rather than the volume of production. Increasing prices while keeping the volume of output fixed enabled Polar Furniture to increase the amount of furniture it could barter since fewer units would be committed to the state.

The fourth factor that favored Polar Furniture was its influential position within the regional wood consortium, the Northern Territories' Wood Association (NTWA). Most enterprises connected to the wood industry belonged to NTWA, from those that cut and processed wood to those that made furniture. NTWA was like a large trading corporation, buying products from its member enterprises at one price while selling them at a higher one. Its control over the sale of wood products depended upon its control over supplies needed by member enterprises. Until 1989 Polar Furniture was part of a huge furniture consortium whose center was in St. Petersburg. When it came to obtaining supplies and particularly new investment Polar was always last in line. Based on its monopoly of the mass production of furniture in the Republic of the North, Polar's situation changed dramatically after it joined NTWA. The association helped Polar obtain supplies not only from within the Republic of the North but also from outside. For example, when a Moscow-based wood consortium failed to supply Polar with high quality plywood, Polar management went immediately to NTWA to request that it cut off that consortium's considerable supply of wood from the Republic of North. NTWA also provided its member enterprises with goods that could be used for barter. Polar, for example, bartered unprocessed wood for needed supplies - wood it obtained through NTWA. Finally, NTWA was able to accumulate foreign exchange from the export of wood and with this bought German machinery for Polar to produce solid wood furniture. Controlling all foreign sales, NTWA hoped to reap the dividends from this machinery when (and if) Polar exported this furniture.

\section{Corporate Strategy}

The renewed strength of Polar Furniture's main division was in large part due to its influence within NTWA. This influence enabled Polar to pur- 
sue a more ambitious strategy with respect to its three smaller subdivisions - soft furniture, bed sets and kitchen cupboards. Before 1987 these three subdivisions were administered by the main plant which negotiated with the state on their behalf. In 1987 the subdivisions went on khozraschet (self-financing) which gave them their own bank accounts and more autonomy to develop their own contacts with both suppliers and buyers. The main division continued to obtain the basic supplies required by all subdivisions, such as pressed wood, but the subdivisions had to find the supplies specific to their production profile.

In 1990 Polar Furniture became an arenda (lease) enterprise, which meant that its property was leased from the state. But it also meant that the subdivisions would be leased from the main division. Arenda itself gave rise to few changes since the advantages that it once offered in terms of taxation and wage funds had been eliminated. However, it did become the pretext for putting relations between the main plant and its subdivisions on a more economic footing. The main division insisted that the subdivisions pay for services provided by the center. Usually arenda agreements would be welcomed by subdivisions of large enterprises since they offered the subdivision more autonomy. But in this case arenda strengthened the position of the main plant which could impose more stringent conditions for continued affiliation. The subdivisions had to comply because they depended on the sponsorship of a major enterprise and because NTWA was not willing to deal with them as independent firms.

The soft furniture subdivision in Arctic City was the exception that proved the rule. The adoption of khozraschet (self-financing) in 1987 coincided with the election of a new subdivision director. The successful candidate was sponsored by the party. He had been the trade union chair at the main plant, often at odds with the General Director who was not unhappy to see him leave. The subdivision grew under the new director but he continued to be a controversial figure from the standpoint of both his subordinates and the management at the main plant. After Polar joined NTWA, top management at the main plant began to develop plans to modernize the soft furniture subdivision, the oldest subdivision in the enterprise. But the subdivision's director wouldn't go along with the plans - he was opposed to producing mattresses and becoming an arenda enterprise. His resistance to reorganization provoked the main plant to adopt a strategy of absorption.
The events leading up to the absorption illustrate the pressures enterprises faced in the uncertain Soviet economic and political environments of 1991. Unlike the production of wall units, soft furniture production was dependent on supplies from outside the Republic of the North - steel springs were brought from Cherepovets, cloth from Cheboksari, foam rubber from Dzerzhinsk, and glue and latex from abroad. For these supplies the subdivision had previously relied on support from the All-Union Ministry, but as this Ministry began to dissolve supplies were more difficult to obtain. Moreover, the state was also trying to impose limits on the amount of furniture that could be bartered. In this bleak situation, the chaotic economic conditions during the winter of 1991 precipitated a rapid decline of production. There were a number of work stoppages due to shortages of materials.

Employees at the soft furniture subdivision began to criticize their managers for not dealing with the crisis. They were spurred on by managers from the main plant who told them that if their subdivision became a department of the main plant working conditions, pay, and food provisions would improve. For workers at the soft furniture division this was an attractive prospect that had the added advantage of removing their unpopular director. In March 1991 employees voted overwhelmingly to become a department of the main plant. Soon afterward disillusion set in when workers began to hear rumors of layoffs that would result from proposed reorganization. In being relegated to the status of a department of the main enterprise employees had lost much of their independence.

In terms of our four conditions for economic success, the situation at the soft furniture subdivision was mixed. On the one hand it produced items that had good barter value and whose price was not state-regulated. On the other hand, its supply situation was precarious because it depended on materials from outside the Republic of the North in a situation where the All-Union Ministry could be of less help. The subdivision was indeed dependent on the main plant which was interested in maintaining its monopoly of both hard and soft furniture production.

The situation at the bed set subdivision was different. Here the move to khozraschet (1987) became the occasion for managers to reduce the number of employees and increase the wages of those who remained. At the same time production was simplified. Unlike soft furniture this subdivision embraced arenda as an opportunity to 
expand and become more autonomous from head offices. Being further from the head plant with looser connections and having potential access to large conglomerates in the local gas and oil industries managers could take a more independent route. But there were limits to that independence because NTWA and Polar's main division still controlled access to the supplies of wood. When the main plant instructed the subdivision to stop producing wall units and concentrate on bed sets they had no alternative but to comply.

A similar situation existed at the third subdivision, seven hundred kilometers north of Arctic City. In 1991 this subdivision switched from the producing wardrobes to producing kitchen cupboards - a more lucrative venture, not only because no kitchen furniture was produced in the Republic of the North, but also because the prices of wardrobes were firmly fixed by the state whereas prices for kitchen cupboards were "contractual" and thus followed a cost plus profit formula. When we visited this subdivision in July 1991, the director was energetically involved in a major reconstruction of its social infrastructure (apartments, hostels, houses) and of the plant itself. The subdivision had managed to establish a direct relation with NTWA which financed the conversion to kitchen cupboards and the importation of special plywood and plastic. However, rampant price inflation, particularly in building materials, had drained away profits and as a result wages had suffered, workers had left, and the trade union was fighting the director. In the winter of 1991 when shortages were at their height, top management at Polar's main plant in Arctic City had appropriated for itself pressed wood destined for this subdivision. According to the irate director the subdivision lost twenty days of production due to the shortage of materials. As ever, lack of control over supplies limited the independence of the subdivision.

Thus, the move to arenda became the occasion for the Polar main division to adopt a dual strategy toward its subdivisions. On the one hand, top management at Polar's main plant used the supposed "autonomy" of the subdivisions as a pretext to reduce its obligations and put relations to subdivisions on a more economic footing. On the other hand, it used its control over supplies to rein in, and if necessary absorb, subdivisions that exhibited "too much" autonomy. Just as within the enterprise head offices used fiscal measures and access to supplies to secure the dependence of subdivisions, so the same was true of the re- lationship between the enterprise and the consortium, NTWA.

\section{Rising Power of Parastatal Conglomerates}

As the central Soviet state became paralyzed by political movements for regional autonomy and as it withdrew from direct regulation of the economy, economic power was decentralized to large monopolistic concerns that controlled local access to resources. NTWA was one such monopoly concern or "parastatal" organization that controlled the wood industry from the logging villages to the logging enterprises to the wood processing plants. In 1988 Polar Furniture and Pitirim Plywood Company joined NTWA and in 1991 the huge paper plant in Arctic City applied for membership (see Figure 2).

It was no easy task for NTWA to manage all these links in the chain of wood manufacture. Most important were the logging enterprises that actually supplied the wood. In 1991 these logging enterprises faced a difficult situation - the Northern Republic's Forestry Ministry controlled the amount of wood that could be cut and workers were leaving due to low pay. These logging enterprises, therefore, tried to circumvent NTWA by entering into their own agreements directly with cooperatives, joint ventures, and other organizations that paid higher prices for their wood. They were supposed to supply NTWA with about 70 percent of their wood at state-regulated prices but in fact they didn't fulfil their contract. Figures we were given showed the supply of wood to NTWA to be falling every year: from 15.5 million cubic meters in 1989 to an anticipated 10 million cubic meters in 1992. The logging enterprises claimed that since NTWA did not fulfil its promises to provide machinery, spare parts, food and so on, they couldn't fulfil their side of the contractual agreement. On the other hand, NTWA still commanded economic resources and political power sufficient to ensure the subordination of the logging enterprises. By cutting off resources NTWA could make life very difficult for enterprises seeking to erode its monopolistic control of wood.

While the logging enterprises were probably too small to stand up to NTWA, larger enterprises might have been able to do so. One enterprise, the Pitirim Plywood Company, had a large appetite for independence and tried to leave NTWA in 1990. The company was founded after World War II. It was situated on a major river and next to the railroad three hours (by road) from Arctic 


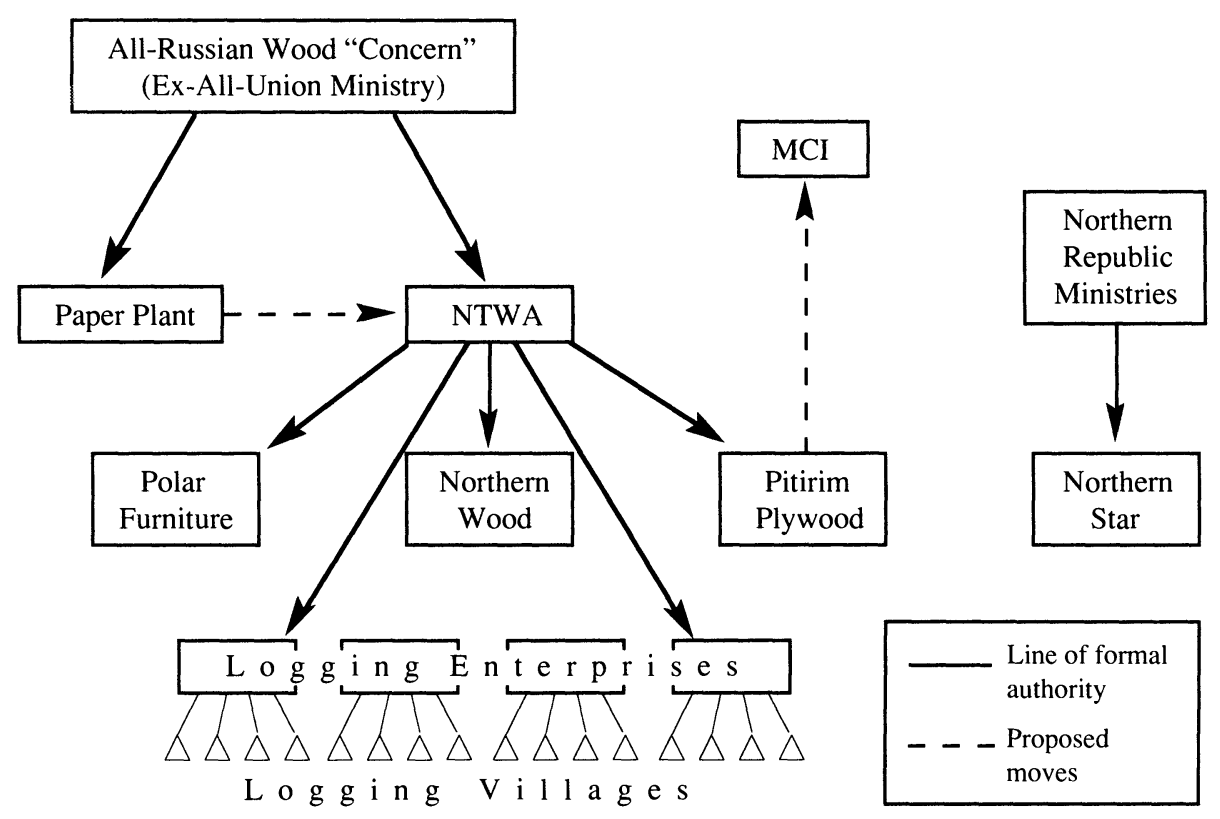

Figure 2. Chain of Wood Manufacture (July 1991)

City. It had been attached to the great paper plant in Arctic City but then became a member of NTWA in 1988. Pitirim management soon became disillusioned with NTWA because NTWA had reneged on its promise to help set up a furniture factory at Pitirim. Indeed, compared to Polar Furniture, Pitirim had received little support in the way of new machinery. NTWA had also failed to organize the delivery of the right quality wood. In $1990 \mathrm{MCI}$, a powerful Moscow based consortium of the machine construction industry, became interested in having Pitirim Plywood as a member enterprise. MCI made some attractive proposals to Pitirim, including an offer of new Soviet-made machinery, lower tax rates, and higher returns from wood exports. The managers of Pitirim organized a meeting in November 1990 at which the employees voted to leave NTWA and join MCI. NTWA immediately threatened to cut off Pitirim's wood supplies. Undaunted, Pitirim Plywood sent the resolution to the Northern Republic's Council of Ministers which denied the enterprise permission to leave NTWA. At the time of our research, MCI was trying to overturn the decision at the level of the All-Union Council of Ministers. Although it was uncertain that more resources would flow to Pitirim Plywood under MCI's sponsorship, it was clear that enterprises had to attach themselves to some large conglomerate that had the resources to assure the delivery of supplies.
The example of Pitirim Plywood raises the question of the distribution of resources within NTWA. An executive board, which included the directors of all the major member enterprises, controlled NTWA's bank and much needed foreign exchange. Which of NTWA's enterprises received resources? It is instructive to compare the fortunes of Polar Furniture and the neighboring wood processing plant, Northern Wood one of the oldest enterprises in Arctic City. Northern Wood exported its wood and thus brought in foreign exchange for NTWA. Foreign exchange was redistributed within NTWA so that, for example, Northern's neighbor Polar Furniture (which exported nothing) could receive new German-made machines. Occupying adjacent areas in the city, the contrasts between the two enterprises were evident. The one was modern, compact, and well organized while the other used unevenly developed technology scattered over a huge complex. In one wages were high, provisions were relatively lavish, and workers were young whereas in the other wages were low, workers were older and in the previous year there had been a strike over poor conditions of work.

How was it that Polar Furniture did so much better than Northern Wood in extracting resources from NTWA? First, as an inducement to join the conglomerate NTWA had offered Polar Furniture the hard currency to purchase new machinery and import materials such as lacquer. 
Second, the General Director of Polar Furniture had a long history of managing enterprises in Northern Republic's wood industry. He had established ties of patronage and an impressive managerial team that NTWA trusted. The General Director of Northern Wood, on the other hand, came from the Regional Party Committee, had much less experience in the wood industry, and on top of that faced a divided management team. Third, NTWA regarded Polar Furniture as a better investment than Northern Wood simply because exporting furniture would be more lucrative than exporting wood. The managerial team at Polar had managed to convince NTWA that they would be able to compete in the international furniture market. Fourth, furniture was more profitable than wood domestically because its prices were unregulated. Moreover, Northern Wood faced competition from the logging enterprises that supplied it with wood. These enterprises had begun processing wood themselves with saw mills they had managed to buy. It was not only more lucrative for the logging enterprises but it was also more efficient to process wood where it was cut. Thus, in supporting Polar rather than Northern Wood, NTWA behaved like a commercial bank investing its money where the returns were likely to be greatest.

Nevertheless NTWA was also a large trading organization that affected every enterprise connected to the wood industry. Take the local tractor equipment factory, Northern Star, which was not a member of NTWA. With 2,000 workers it was one of the biggest factories in Arctic City. It produced special equipment used in the logging villages for cutting and hauling logs. The equipment was attached to tractors imported from another territory. Northern Star monopolized the Republic's production of this equipment, which it sold directly to the logging enterprises at "contractual prices." In 1991 the central Ministry of the Russian Federation was still trying to dictate the distribution of the equipment but it could no longer guarantee supplies. This meant that Northern Star had to barter its equipment for wood, wood that was then used to buy new machinery, obtain steel supplies, and so on. At the same time, the state ordered fewer and fewer tractors installed with the equipment (the number produced a year dropped from 1100 to 710 ) as the logging enterprises themselves became both more autonomous and less able to afford new machinery. Reflecting these difficult circumstances, Northern Star's average wage was only a little more than half that of Polar Furniture and the waiting list for apartments was 17 to 22 years, twice as long as at Polar Furniture. Northern Star had begun producing trailers for cars and its managers were thinking about manufacturing saw mills. But no one knew where the necessary capital investment would come from to reconstruct an old and disorganized plant. Without a wealthy sponsor the situation at the plant would only deteriorate. NTWA was an obvious candidate but why would this already overstretched conglomerate find Northern Star an attractive investment?

The most surprising testimony to NTWA's rising power was the desire of Arctic City's huge paper plant to become a member. The paper plant had always prided itself in its independence from NTWA. It had been established directly by the All-Union ministry to produce quality paper for books and journals throughout the Soviet Union. It used expensive Finish and Austrian technology. In 1991, reflecting its own weaker position, the central Ministry cut its orders for paper by 50 percent. Taking advantage of this turn of events, NTWA threatened to reduce the paper mill's supply of wood by a corresponding amount. Since NTWA had a virtual monopoly over the distribution of wood, the paper mill found itself under considerable pressure to join NTWA and surrender its independence. For NTWA the accession would create many headaches, particularly with respect to the supply of wood and maintenance and replacement of foreign machinery, but NTWA's bartering power would be considerably enhanced. Again, the withdrawal of support from central state organs led even the largest enterprises to seek affiliation with parastatal conglomerates who thereby became even more powerful. The collapse of the party state, rather than creating markets and competition, strengthens hierarchies and monopolies.

\section{FROM STATE SOCIALISM TO MERCHANT CAPITALISM}

Do all the proclamations and all the plans for a transition to a market economy mean that the Soviet system is actually moving toward capitalism? To answer this question requires going beyond political decrees or ideological mobilization to examine real changes in economic relations. The dynamics of capitalism rest on the continual pressure to transform products and work organization in order to maintain profit in a competitive market. Unable to control market relations management is forced to concentrate on the 
transformation of production. On the other hand, in state socialism, supply shortages and worker control make managerial control of production impossible - so management concentrates on bargaining with the state. The successful enterprise is one that succeeds in such bargaining and is thereby able to forge a stable compromise with its workers. To what extent has this changed?

\section{Amplifying the Past}

Our case study suggests that with the withering away of the party state the Soviet economy, far from collapsing or transforming itself, has assumed an exaggerated version of its former self. ${ }^{14}$ The dislocation between the shop floor and external bargaining remains. What has changed is the form of the external bargaining. Whereas previously the enterprise bargained through hierarchical channels with regional ministries, the regional party committee, territorial conglomerates, and All-Union ministries, now the number of channels is reduced, in our case study primarily to the single conglomerate, NTWA. The collapse of the party state has led to the consolidation of monopoly associations into parastatal conglomerates that seek to control all transactions.

However, in substituting themselves for the party state in the hierarchical order, the parastatals have not actually been able to maintain the same monopoly over lateral ties. The parastatals do not command the power necessary to guarantee supplies to their members who are therefore compelled to use a portion of their production to obtain supplies directly through barter. Often the most intense negotiations concern the percentage of production that the parastatal could claim as "state orders" and how much would be left for barter at the discretion of the enterprise. As parastatals fail to deliver what enterprises need, barter increases which in turn further undermines the strength of the parastatal.

Of course, barter relations between enterprises existed under the old regime, but these were mediated either through tolkachi (pushers) who operated semilegally between enterprises or through

\footnotetext{
${ }^{14}$ Based on our survey of enterprises in Arctic City, we believe our conclusions can be generalized. But we only examined civilian production. Military enterprises are known to have strict discipline, effective work organization and few chronic supply problems (Zaslavsky 1982, chap. 3; n.d.). To what extent such work organization continues to prevail in the military sector, particularly where there is conversion to civilian production, we do not know.
}

regional party secretaries who would call their counterparts in other regions to help obtain urgently required supplies (Hough 1969; Hewett 1988, pp. 162-70; Zaslavskaya 1990, pp. 60-73). So, although lateral exchange did exist, it was carefully monitored. The party state limited the autonomy of enterprises through its control of the promotion and demotion of enterprise directors. If managers did not comply with plan targets, they could lose their jobs or even be asked to "put their party card on the table." Now managers have greater autonomy to bargain laterally which in turn gives them more leverage vertically.

One should not exaggerate the effects of the collapse of the party state. True, in our case study the all-important department for wood and forestry in the Regional Party offices was liquidated at the beginning of 1991, and across the central square of Arctic City at the Council of Ministers a completely new ministry was created. And true, this fledgling ministry is less effective than the previous department in the Regional Party offices in controlling the production chain of the wood industry. It does not, for example, have the power to remove directors from their positions. At the same time, many of the key party bureaucrats have found their way into new positions of power where they can reproduce their control over the economy. The plethora of cooperatives that have sprung up to mediate the bargaining and trading between enterprises are often established and run by former party secretaries. ${ }^{15}$ What they did before in the name of "communism" they now do as self-proclaimed "business men." The ideology may have changed but the basic functions are the same.

\footnotetext{
${ }^{15}$ Similar reorganization of old relations into new forms have been found in Poland (Staniszkis 1991) and Hungary (Stark 1990; Burawoy and Lukács 1992, chap. 6). Interestingly, the literature on Soviet cooperatives tends to focus on bureaucratic resistance to their formation (Jones and Moskoff 1991; Slider 1991) and overlooks the way the party has been able to reconstitute itself through cooperatives. In 1991 cooperatives occupied the bottom floor of the Regional Party headquarters in Arctic City. One of them, called "Prognos," was a sociology cooperative organized to undertake surveys of public opinion to foster democratic responsiveness of leaders. Its president had been the first party secretary for ideology. In many quarters sociology has become the new ideology to succeed Marxism-Leninism. Thus, university departments of "Philosophy and Scientific Communism" have been renamed departments of "Philosophy and Sociology" but the incumbents remain the same.
} 
To be sure economic relations are less politicized. They are also increasingly carried out with a view to augmenting "profit." Parastatal conglomerates such as NTWA conduct their bargaining in the language of profitability. But the profits come from monopoly, from barter, from valuta (foreign currency) and not from production. The newly created banks loan money for trading ventures not productive ventures. Cooperatives, small enterprises, and even joint ventures, the supposed harbingers of capitalism, are barred from independent productive activities by the monopolistic activities of state enterprises, banks, and parastatal conglomerates. ${ }^{16}$

The pursuit of profit through trade and monopoly dovetails well with the retention of worker control over production. Indeed, if anything, worker control is strengthened. First, increasing shortages of supplies leads to intensified anarchy on the shop floor and thus to spontaneous selforganization by workers. Second, when supply shortages increase managers are more preoccupied with searching for materials and have even less time to regulate production. Third, as agents of managerial control shop floor supervisors become even weaker with the demise of party appointments. Fourth, monetary incentives become less effective as a means of regulating work because there is less to buy with extra wages. To elicit the cooperation of workers management must provide reward in kind, particularly food. In this regard, Polar was in a better position than most enterprises because it manufactured a product that could be bartered for food. Less fortunate enterprises must deploy alternative strategies to forge compromises with workers, such as creating "cooperatives" or "small enterprises" within plants to employ workers in overtime for higher wages (Burawoy and Hendley forthcom-

\footnotetext{
${ }^{16}$ Kroll (1991) showed how government programs to deconcentrate Soviet industry were based on an overestimation of the effectiveness of political decree. The programs assumed that "competitive industrial structure can be created by bureaucratic fiat, rather than developing as a consequence of market forces" (p. 171). Instead of breaking up monopolies and regulating prices (then government policy) Kroll proposes promoting the unrestricted growth of a private sector alongside the state sector, the deregulation of prices and opening the country to international competition. This is similar to Kornai's (1990) program for a Hungarian "road to a free economy." Both Kroll and Kornai underestimate the power of existing monopolies to protect themselves against any competition - internal or external.
}

ing). But the result is the same: control is ceded to the shop floor.

\section{The Development of Underdevelopment}

The double anarchy of relations in production and relations of production can be seen as an exaggeration of the old economic system or as the harbinger of a new order. That new order is based on domination by monopolies whose powers reside in control of access to supplies. As we have seen, this economic system is driven by the pursuit of profit that comes primarily from trade rather than from transforming production. Work is in effect "put out" to worker collectives in enterprises. These are characteristics of merchant capitalism. "The independent and predominant development of merchant's capital is tantamount to the non-subjection of production to capital" (Marx [1894] 1967, pp. 327-28). However, merchant capital does not evolve naturally into bourgeois capitalism. It contains no imminent tendencies toward self-transformation. Quite the opposite: "[Merchant capital] cannot by itself contribute to the overthrow of the old mode of production, but tends rather to preserve and retain it as its precondition" (Marx [1894] 1967, p. 334).

The factors determining a successful transition to industrial capitalism vary with the specific context in which merchant capital prevails. In the Soviet case such a transition would require replacing monopolies with competitive enterprises, barter with market exchange, and worker control with managerial control. Since monopoly, barter and worker control form a mutually reinforcing triad, nothing short of revolution could transform the Soviet economic system into industrial capitalism. Certainly liberal democracy cannot be the instrument of such a change since it is powerless to counter merchant capital's tendency to fragment the Soviet Union into local "suzerainties" (Humphrey 1991; Verdery 1991). Merchant capitalism becomes the economic basis for intense nationalism and localism. As the Soviet Union disintegrates, nations and regions will try to maximize their control over trade by controlling the flow of goods across their borders, by introducing their own currencies, and by regulating export licenses.

If liberal democracy is not a remedy, what about that other panacea: the world market? In general external economic pressures cannot by themselves compel a transition to bourgeois capitalism without internal agents who have both the interest and the capacity to promote such a tran- 
sition (Brenner 1976, 1977). But do such internal social forces currently exist? Proposals to create an independent capitalist sector ignore the strength of merchant capital. Foreign investors have so far found it impossible to operate independently of the parastatal conglomerates which control supplies and infrastructure. Not surprisingly, therefore, foreign capital works with these conglomerates to provide Western consumer goods and extract raw materials. "The independent development of merchant's capital, therefore, stands in inverse proportion to the general economic development of society" (Marx [1894] 1967, p. 328). As in the Third World, foreign capital enters in the form of merchant capital and thereby deepens underdevelopment because it leaves production largely untouched (Kay 1975, particularly chap. 5).

The advocates of shock therapy promise recovery. Even if the pain is great, the transition from a command economy to a market economy will leave everyone better off in the end. This is an empty promise, reminiscent of the communist utopia. Like communism, the popular models of capitalism fail to demonstrate their viability or feasibility, just as they provide an ideological cover for a very different form of existing society. Thus, it is by no means obvious that "a free market economy" generating "universal opulence" is viable anywhere in the modern world system let alone in the new Commonwealth of Independent States. Second, even if the model were internally viable, there may be no feasible way of getting there once account is taken of the resilience of an economy based on barter, monopoly, and worker control as well as the forces of international capitalism. Third, the ideology of the market economy, which is now almost as pervasive in Russia as was the ideology of communism before, obscures the enormous gap between merchant capitalism and bourgeois industrial capitalism. This gap is no less daunting than the one that separated state socialism from the promise of communism.

We are not saying that the Russian economy is heading for collapse. Merchant capitalism will continue to reproduce itself, albeit on a diminishing scale. Parastatal conglomerates will seek alliances with the more lucrative enterprises and let the others fend for themselves. Thus, successful enterprises like Polar Furniture will continue to exist, although at the expense of failing enterprises such as Rezina. We are saying, however, that the solution to economic decline does not lie in monetary stabilization, privatization, liberaliza- tion of prices and the lowering of tariffs. Merchant capital is quite compatible with all these economic reforms. ${ }^{17}$ In the face of competition merchant capitalism preserves and deepens the underdevelopment of the system of production out of which it sprung and upon which it is founded.

\section{Epilogue: The Radiant Past}

There is, of course, an alternative scenario implied in the fourth cell of Figure 1, namely syndicalism. Conceivably, existing forms of worker control could be extended upwards so that the economy would be reconstructed from below rather than fragmented from above. Such a movement can be identified in the insurgency of the coal miners who in 1989 and 1991 broke the social contract that bound them to their bosses and undertook mammoth political as well as economic strikes (Friedgut and Siegelbaum 1990; Rutland 1990; Connor 1991, chapter 7).

But the miners are an exception. Far from becoming militant or radical, the workers in Arctic City became more and more demoralized as perestroika unfolded. They are humiliated by the way they have to live: "We'll soon be going back to the woods ..."; "This is no civilized country. ..." They ask me why I didn't visit them five years ago: "Things were much better then." When something went wrong on the shop floor, they blamed the reign of bardak (chaos): "We need order. The old system worked much better." "So you want to return to the old system?" I ask. And they reply, "On the one hand, it wouldn't be too bad; on the one hand at least there would be order, on the one hand...." They never get to the other hand.

Certainly, for most the future looks bleaker than the past. A young apprentice asks me whether life is better "over there?" I shrug my shoulders and say it depends on who you are. I ask him what he thinks. "Of course, it's better," he replies, “There's everything there." For him and his generation capitalism is simply a dream, a fantasy displayed on television in second-rate American films. It has, of course, a special magic in a shortage econ-

\footnotetext{
${ }^{17}$ Even in Poland, the supposed success story of "shock therapy" through market reform, we find farmers responding to the flood of cheap food from abroad by retreating into closed cycle production. Encircled by trading monopolies, their entrepreneurship has been stifled even though they are well endowed with private property (Salameh forthcoming).
} 
omy. But it is no less utopian than the idea of socialism in the United States. It is not something workers can ever imagine coming to Arctic City. So while in the West we celebrate the "collapse of communism," at Polar workers mourn for the past and despair for the future.

MICHAEL BURAWOY teaches sociology at the University of California, Berkeley. He is a coauthor of Ethnography Unbound: Power and Resistance in the Modern Metropolis and The Radiant Past: Ideology and Reality in Hungary's Road to Capitalism.

Pavel KRotov has a Candidate degree from the Institute of Sociology in Moscow and is interested in political influences on economic processes. He has also written on Pitirim Sorokin's life in Russia.

\section{REFERENCES}

Andrle, Vladimir. 1988. Workers in Stalin's Russia. New York: St. Martin's Press.

Asselain, Jean-Charles. 1981. Planning and Profits in Socialist Economies. London: Routledge and Kegan Paul.

Aslund, Anders. 1989. Gorbachev's Struggle for Economic Reform. Ithaca: Cornell University Press.

Bahro, Rudolf. 1976. The Alternative in Eastern Europe. London: Verso Books.

Bauer, Tomás. 1978. "Investment Cycles in Planned Economies." Acta Oeconomica 21:243-60

Berliner, Joseph. 1957. Factory and Manager in the USSR. Cambridge: Harvard University Press. 1976. The Innovation Decision in Soviet Industry. Cambridge: Massachusetts Institute of Technology Press.

Bettleheim, Charles. 1976. Economic Calculation and Forms of Property. London: Routledge and Kegan Paul.

Brenner, Robert. 1976. "Agrarian Class Structure and Economic Development in Pre-Industrial Europe." Past and Present 70:30-75.

. 1977. "The Origins of Capitalist Development: A Critique of Neo-Smithian Marxism." New Left Review 104:25-92.

Burawoy, Michael. 1979. Manufacturing Consent. Chicago: University of Chicago Press.

1985. The Politics of Production. London:

Verso Books.

Burawoy, Michael and Kathryn Hendley. Forthcoming. "Between Perestroika and Privatization: Divided Strategies and Political Crisis in a Soviet Enterprise." Soviet Studies 44(3).

Burawoy, Michael and János Lukács. 1992. The Radiant Past: Ideology and Reality in Hungary's Road to Capitalism. Chicago: University of Chicago Press.

Connor, Walter D. 1991. The Accidental Proletariat. Princeton: Princeton University Press.

Edwards, Richard. 1979. The Contested Terrain. New
York: Basic Books.

Engels, Friederich. [1880] 1978. "Socialism: Utopian and Scientific." Pp. 683-717 in The Marx-Engels Reader, edited by R. Tucker. New York: W. W. Norton.

Filtzer, Donald. 1986. Soviet Workers and Stalinist Industrialization. Armonk, NY: M. E. Sharpe.

Fligstein, Neil. 1990. The Transformation of Corporate Control. Cambridge: Harvard University Press.

Friedgut, Theodore and Lewis Siegelbaum. 1990. "Perestroika From Below: The Soviet Miners' Strike and Its Aftermath." New Left Review 181:5-32.

Friedman, Andrew. 1977. Industry and Labor. London: MacMillan.

Granick, David. 1954. Management of the Industrial Firm in the USSR. New York: Columbia University Press.

1967. Soviet Metal-Fabricating and Economic Development. Madison: University of Wisconsin Press.

1987. Job Rights in the Soviet Union. Cambridge, England: Cambridge University Press.

Hendley, Kathryn. Forthcoming. "The Quest for Rational Labor Allocation Within Soviet Enterprises: Internal Transfers Before and During Perestroika." In New Voices in Soviet Studies, edited by S. Solomon. Armonk, NY: M. E. Sharpe.

Hewett, Ed. 1988. Reforming the Soviet Economy. Washington, DC: Brookings Institute.

Holubenko, M. 1975. "The Soviet Working Class." Critique 4:5-26.

Hough, Jerry. 1969. The Soviet Prefects. Cambridge: Harvard University Press.

Humphrey, Caroline. 1991. "'Icebergs', Barter, and the Mafia in Provincial Russia." Anthropology Today $7(2): 8-13$.

Jones, Anthony and William Moskoff. 1991. Ko-ops: The Rebirth of Entrepreneurship in the Soviet Union. Bloomington: University of Indiana Press.

Kay, Geoffrey. 1975. Development and Underdevelopment: A Marxist Analysis. New York: St. Martin's Press.

Konrád, György and Iván Szelényi. 1979. The Intellectuals on the Road to Class Power. New York: Harcourt, Brace, and Jovanovich.

Kornai, János. 1959. Overcentralization in Economic Administration. Oxford, England: Oxford University Press.

1980. The Economics of Shortage. 2 vols. Amsterdam: North Holland Publishing Company. 1986. "The Hungarian Reform Process:

Visions, Hopes and Reality." Journal of Economic Literature 24:1687-1737.

1990. The Road to the Free Economy:

Shifting From a Socialist System, the Example of Hungary. New York: W. W. Norton.

Kroll, Heidi. 1991. "Monopoly and Transition to the Market." Soviet Economy 7:143-74.

Kushnirsky, Fyodor. 1991. "Economic Reform Without Direction." Pp. 178-203 in Perestroika at the 
Crossroads, edited by A. Rieber and A. Rubinstein. Armonk, NY: M. E. Sharpe.

Lampert, Nick. 1985. Whistleblowing in the Soviet Union. London: MacMillan. 1986. "Job Security and the Law in the USSR." Pp. 256-77 in Labour and Employment in the USSR, edited by D. Lane. New York: New York University Press.

Lane, David. 1987. Soviet Labour and the Ethic of Communism. Boulder, CO: Wheatsheaf Books.

Lash, Scott and John Urry. 1987. The End of Organized Capitalism. Madison: University of Wisconsin Press.

Lewin, Moshe. 1974. Political Undercurrents in Soviet Economic Debates. Princeton: Princeton University Press.

Linz, Susan. 1988. "Managerial Autonomy in Soviet Firms." Soviet Studies 40:175-95.

Malia, Martin. 1991. "The August Revolution." The New York Review of Books 26(Sept.):22-28.

Marx, Karl. [1859] 1978. "Preface" to A Contribution to the Critique of Political Economy. Pp. 4-5 in The Marx-Engels Reader, edited by R. Tucker. New York: W. W. Norton.

. [1894] 1967. Capital. Vol.3. New York: International Publishers.

Nove, Alec. 1965. The Soviet Economy. New York: Praeger.

1983. The Economics of Feasible Socialism. London: George Allen and Unwin.

Osborn, Robert. 1991. "Phasing Out the Party Apparat as Economic Manager." Pp. 157-77 in Perestroika at the Crossroads, edited by R. Rieber and A. Rubinstein. Armonk, NY: M. E. Sharpe.

Piore, Michael and Charles Sabel. 1984. The Second Industrial Divide. New York: Basic Books.

Pomorski, Stanislaw. 1991. "Restructuring the System of Ownership in the USSR." Pp. 204-31 in Perestroika at the Crossroads, edited by A. Rieber and A. Rubinstein. Armonk, NY: M. E. Sharpe.

Przeworski, Adam. 1991. Democracy and the Market: Political and Economic Reforms in Eastern Europe and Latin America. Cambridge, England: Cambridge University Press.

Rutland, Peter. 1990. "Labor Unrest and Movements in 1989 and 1990." Soviet Economy 6:345-84.

Sachs, Jeffrey and David Lipton. 1990. "Poland's Economic Reform." Foreign Affairs 69:47-66.

Salameh, Slawomira. Forthcoming. "Bitter Harvest: The Transition of Post-Socialist Poland to a Market Economy." Ph.D. dissertation, University of California, Berkeley.

Siegelbaum, Lewis. 1988. Stakhanovism and the Pol- itics of Productivity in the USSR, 1935-1941. Cambridge, England: Cambridge University Press.

Slider, Darrell. 1987. "The Brigade System in Soviet Industry: An Effort to Restructure the Labor Force." Soviet Studies 39:388-405.

1991. "Embattled Entrepreneurs: Soviet Cooperatives in an Unreformed Society." Soviet Studies 43:797-821.

Smith, Vicki. 1990. Managing in the Corporate Interest. Berkeley: University of California Press.

Staniszkis, Jadwiga. 1991. "'Political Capitalism' in Poland." East European Politics and Societies 5:127-41.

Stark, David. 1986. "Rethinking Internal Labor Markets: New Insights From a Comparative Perspective." American Sociological Review 51:492-504. 1989. "Coexisting Organizational Forms in Hungary's Emerging Mixed Economy." Pp. 13768 in Remaking the Economic Institutions of Socialism, edited by D. Stark and V. Nee. Stanford: Stanford University Press.

1990. "Privatization in Hungary: From Plan to Market or From Plan to Clan?" East European Politics and Societies 4:351-92

Ticktin, Hillel. N.d. "The Political Economy of Class in the Transitional Epoch." Critique 20-21:7-26.

Verdery, Katherine. 1991. "Transition from Socialism to Feudalism?" Unpublished draft for the fourth lecture of the Lewis Henry Morgan Memorial Lectures, The Transition from Socialism: Anthropology and Eastern Europe. The Johns Hopkins University, Baltimore.

Voskamp, Ulrich and Volker Wittke. 1991. "Industrial Restructuring in the Former German Democratic Republic (GDR): Barriers to Adaptive Reform Become Downward Development Spirals." Politics and Society 19:341-71.

Weber, Max. 1958. The Protestant Ethic and the Spirit of Capitalism. New York: Charles Scribner's.

Wood Stephen, ed. 1989. The Transformation of Work? London: Unwin Hyman.

Yanowitch, Murray. 1991. Controversies in Soviet Social Thought. Armonk, NY: M. E. Sharpe.

Zaslavskaya, Tatyana. 1990. The Second Socialist Revolution: An Alternative Socialist Strategy. London: I. B. Tauris.

Zaslavsky, Victor. 1982. The Neo-Stalinist State. Armonk, NY: M. E. Sharpe.

N.d. "Soviet Transition to Market Economy: State-Dependent Workers, Populism and Nationalism." Unpublished manuscript, Department of Sociology, Memorial University of Newfoundland. 
http://www.jstor.org

\section{LINKED CITATIONS}

- Page 1 of 3 -

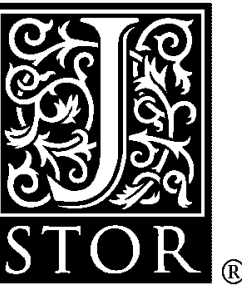

You have printed the following article:

The Soviet Transition from Socialism to Capitalism: Worker Control and Economic Bargaining in the Wood Industry

Michael Burawoy; Pavel Krotov

American Sociological Review, Vol. 57, No. 1. (Feb., 1992), pp. 16-38.

Stable URL:

http://links.jstor.org/sici?sici=0003-1224\%28199202\%2957\%3A1\%3C16\%3ATSTFST\%3E2.0.CO\%3B2-R

This article references the following linked citations. If you are trying to access articles from an off-campus location, you may be required to first logon via your library web site to access JSTOR. Please visit your library's website or contact a librarian to learn about options for remote access to JSTOR.

\section{[Footnotes]}

\footnotetext{
${ }^{3}$ Rethinking Internal Labor Markets: New Insights from a Comparative Perspective David Stark

American Sociological Review, Vol. 51, No. 4. (Aug., 1986), pp. 492-504.

Stable URL:

http://links.jstor.org/sici?sici=0003-1224\%28198608\%2951\%3A4\%3C492\%3ARILMNI\%3E2.0.CO\%3B2-\%23
}

\footnotetext{
${ }^{4}$ Between Perestroika and Privatisation: Divided Strategies and Political Crisis in a Soviet Enterprise

Michael Burawoy; Kathryn Hendley

Soviet Studies, Vol. 44, No. 3. (1992), pp. 371-402.

Stable URL:

http://links.jstor.org/sici?sici=0038-5859\%281992\%2944\%3A3\%3C371\%3ABPAPDS\%3E2.0.CO\%3B2-7
}

${ }^{11}$ The Brigade System in Soviet Industry: An Effort to Restructure the Labour Force Darrell Slider

Soviet Studies, Vol. 39, No. 3. (Jul., 1987), pp. 388-405.

Stable URL:

http://links.jstor.org/sici?sici=0038-5859\%28198707\%2939\%3A3\%3C388\%3ATBSISI\%3E2.0.CO\%3B2-2

NOTE: The reference numbering from the original has been maintained in this citation list. 
http://www.jstor.org

\section{LINKED CITATIONS}

- Page 2 of 3 -

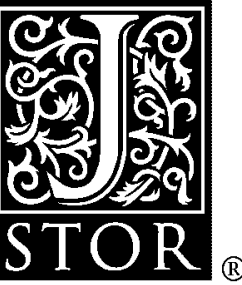

\footnotetext{
${ }^{12}$ Between Perestroika and Privatisation: Divided Strategies and Political Crisis in a Soviet Enterprise

Michael Burawoy; Kathryn Hendley

Soviet Studies, Vol. 44, No. 3. (1992), pp. 371-402.

Stable URL:

http://links.jstor.org/sici?sici=0038-5859\%281992\%2944\%3A3\%3C371\%3ABPAPDS\%3E2.0.CO\%3B2-7
}

${ }^{13}$ Between Perestroika and Privatisation: Divided Strategies and Political Crisis in a Soviet Enterprise

Michael Burawoy; Kathryn Hendley

Soviet Studies, Vol. 44, No. 3. (1992), pp. 371-402.

Stable URL:

http://links.jstor.org/sici?sici=0038-5859\%281992\%2944\%3A3\%3C371\%3ABPAPDS\%3E2.0.CO\%3B2-7

${ }^{15}$ Embattled Entrepreneurs: Soviet Cooperatives in an Unreformed Economy

Darrell Slider

Soviet Studies, Vol. 43, No. 5. (1991), pp. 797-821.

Stable URL:

http://links.jstor.org/sici?sici=0038-5859\%281991\%2943\%3A5\%3C797\%3AEESCIA\%3E2.0.CO\%3B2-J

\section{References}

Agrarian Class Structure and Economic Development in Pre-Industrial Europe

Robert Brenner

Past and Present, No. 70. (Feb., 1976), pp. 30-75.

Stable URL:

http://links.jstor.org/sici?sici=0031-2746\%28197602\%290\%3A70\%3C30\%3AACSAED\%3E2.0.CO\%3B2-J

Between Perestroika and Privatisation: Divided Strategies and Political Crisis in a Soviet Enterprise

Michael Burawoy; Kathryn Hendley

Soviet Studies, Vol. 44, No. 3. (1992), pp. 371-402.

Stable URL:

http://links.jstor.org/sici?sici=0038-5859\%281992\%2944\%3A3\%3C371\%3ABPAPDS\%3E2.0.CO\%3B2-7

NOTE: The reference numbering from the original has been maintained in this citation list. 
http://www.jstor.org

\title{
LINKED CITATIONS \\ - Page 3 of 3 -
}

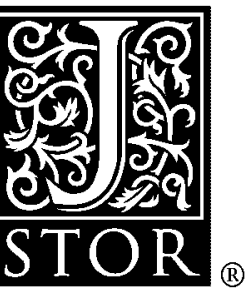

\author{
'Icebergs', Barter, and the Mafia in Provincial Russia \\ Caroline Humphrey \\ Anthropology Today, Vol. 7, No. 2. (Apr., 1991), pp. 8-13. \\ Stable URL: \\ http://links.jstor.org/sici?sici=0268-540X\%28199104\%297\%3A2\%3C8\%3A\%27BATMI\%3E2.0.CO\%3B2-S
}

The Hungarian Reform Process: Visions, Hopes, and Reality

János Kornai

Journal of Economic Literature, Vol. 24, No. 4. (Dec., 1986), pp. 1687-1737.

Stable URL:

http://links.jstor.org/sici?sici=0022-0515\%28198612\%2924\%3A4\%3C1687\%3ATHRPVH\%3E2.0.CO\%3B2-I

\section{Managerial Autonomy in Soviet Firms}

Susan J. Linz

Soviet Studies, Vol. 40, No. 2. (Apr., 1988), pp. 175-195.

Stable URL:

http://links.jstor.org/sici?sici=0038-5859\%28198804\%2940\%3A2\%3C175\%3AMAISF\%3E2.0.CO\%3B2-V

The Brigade System in Soviet Industry: An Effort to Restructure the Labour Force

Darrell Slider

Soviet Studies, Vol. 39, No. 3. (Jul., 1987), pp. 388-405.

Stable URL:

http://links.jstor.org/sici?sici=0038-5859\%28198707\%2939\%3A3\%3C388\%3ATBSISI\%3E2.0.CO\%3B2-2

\section{Embattled Entrepreneurs: Soviet Cooperatives in an Unreformed Economy}

Darrell Slider

Soviet Studies, Vol. 43, No. 5. (1991), pp. 797-821.

Stable URL:

http://links.jstor.org/sici?sici=0038-5859\%281991\%2943\%3A5\%3C797\%3AEESCIA\%3E2.0.CO\%3B2-J

\section{Rethinking Internal Labor Markets: New Insights from a Comparative Perspective}

David Stark

American Sociological Review, Vol. 51, No. 4. (Aug., 1986), pp. 492-504.

Stable URL:

http://links.jstor.org/sici?sici=0003-1224\%28198608\%2951\%3A4\%3C492\%3ARILMNI\%3E2.0.CO\%3B2-\%23

NOTE: The reference numbering from the original has been maintained in this citation list. 